\title{
IfIISGUC.ORG
}

"iş, GÜÇ" ENDÜSTRi iLişKILERI VE INSAN KAYNAKLARI DERGISi
"IS, GUC" INDUSTRIAL RELATIONS AND HUMAN RESOURCES JOURNAL

\section{İş Performansının Sağlanmasında Çalışanın Duygusal Emeğinin ve Örgütte Güven Algısının Etkileri}

\author{
Dr. Memduh BEGENIRBAŞ \\ Kara Harp Okulu Dekanlığı, İşletme Bölüm Başkanlığı
}

Dr. Ercan TURGUT

Kara Harp Okulu Dekanlığı

\author{
Temmuz/July 2014, Cilt/Vol: 16, Say1/Num: 3, Page: 131-149 \\ ISSN: 1303-2860, DOI: 10.4026/1303-2860.2014.0253.x
}

Makalenin on-line kopyasına erişmek için / To reach the on-line copy of article: $\mathrm{http}: / / \mathrm{w} w \mathrm{w}$.isguc.org/?p=article\&id=559\&cilt=16\&sayi=3\&yil=2014

Makale İçin İletişim/Correspondence to:

Memduh BEĞENİRBAŞ, Kara Hap Okulu, email: mbegenirbas@kho.edu.tr 


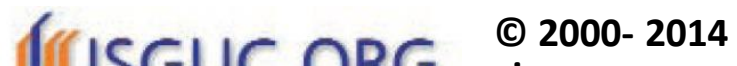 \\ "Işü̈ç" Endüstri iliş̧ileri ve İnsan Kaynakları Dergisi "Iş̧ü̧ç" Industrial Relations and Human Resources Journal
}

\author{
Temmuz/July 2014, Cilt/Vol: 16, Say1/Num: 3, Page: 131-149 \\ ISSN: 1303-2860, DOI: 10.4026/1303-2860.2014.0259.x
}

İş,Güç, Endüstri İlişkileri ve İnsan Kaynaklan Dergisi, yılda dört kez yayınlanan hakemli, bilimsel elektronik dergidir.

Çalışma hayatına ilişkin makalelere yer verilen derg inin temel amacı, belirlenen alanda akademik gelişime ve paylaşıma katkıda bulunmaktadır.

İs, Güç, Endüstri İlişkileri ve İnsan Kaynaklan Dergisi, 'Türkçe' ve 'Ingilizce' olarak ikidilde makale yayinlanmaktadır.

Dergimiz İş, Güç; ulusal ve uluslararası birçok indekste taranmaktadır. (Cabells Directory, Ebsco Socindex, Index Islamicus, Index Copernicus, Worldwide Political Science Abstracts, Sociological Abstract, Ulakbim Sosyal BilimlerVeritan, Asos Index)

\section{Editörler Kurulu / Editorial Board}

Aşkın Keser (Uludă̆ University)

K.Ahmet Sevimli (Uludă̆ University)

Şenol Baştürk (Uludağ University)

\section{Editör/Editor in Chief}

Şenol Baştürk (Uludăg University)

\section{Uygulama / Design}

Yusuf Budak (Kocaeli University)

Tarandı̆̆ı Indeksler/Indexes

ASOS INDEX

CABELLS DIRECTORY

EBSCO SOCINDEX

Index ISLAMICUS

Index COPERNICUS

Sociological Abstract

ULAKBIM Sosyal Bilimler

Veritanı

Worldwide Political Science

Abstracts

\author{
Yayın Kurulu / Editorial Board \\ Yrd.Doç.Dr.Zerrin Fırat (Uludă̆ University) \\ Prof.Dr.Aşkın Keser (Uludağ University) \\ Prof.Dr.Ahmet Selamoğlu (Kocaeli University) \\ Yrd.Doç.Dr.Ahmet Sevimli (Uludă̆ University) \\ Doç.Dr.Abdulkadir Şenkal (Kocaeli University) \\ Doç.Dr.Gözde Yılmaz (Marmara University) \\ Yrd.Doç.Dr.Dr.Memet Zencirkıran (Uludăg University)
}

Uluslararası Danışma Kurulu / International Advisory Board

Prof.Dr.Ronald Burke (York University-Kanada)

Assoc.Prof.Dr.Glenn Dawes (James Cook University-Avustralya)

Prof.Dr.Jan Dul (Erasmus University-Hollanda)

Prof.Dr.Alev Efendioğlu (University of San Francisco-ABD)

Prof.Dr.Adrian Furnham (University College London-Ingiltere)

Prof.Dr.Alan Geare (University of Otago- Yeni Zellanda)

Prof.Dr. Ricky Griffin (TAMU-Texas AEM University-ABD)

Assoc. Prof. Dr. Diana Lipinskiene (Kaunos University-Litvanya)

Prof.Dr.George Manning (Northern Kentucky University-ABD)

Prof. Dr. William (L.) Murray (University of San Francisco-ABD)

Prof.Dr.Mustafa Özbilgin (Bruner University-UK)

Assoc. Prof. Owen Stanley (James Cook University-Avustralya)

Prof.Dr.Işık Urla Zeytinoğlu(McMaster University-Kanada)

$$
\begin{aligned}
& \text { Ulusal Danışma Kurulu / National Advisory Board } \\
& \text { Prof.Dr.Yusuf Alper (Uludă̆ University) } \\
& \text { Prof.Dr.Veysel Bozkurt (İstanbul University) } \\
& \text { Prof.Dr.Toker Dereli (Işık University) } \\
& \text { Prof.Dr.Nihat Erdoğmuş (İstanbul Şehir University) } \\
& \text { Prof.Dr.Ahmet Makal (Ankara University) } \\
& \text { Prof.Dr.Ahmet Selamo ğlu (Kocaeli University) } \\
& \text { Prof.Dr.Nadir Suğur (Anadolu University) } \\
& \text { Prof.Dr.Nursel Telman (Maltepe University) } \\
& \text { Prof.Dr.Cavide Uyargil (İstanbul University) } \\
& \text { Prof.Dr.Engin Yıldırım (Anayasa Mahkemesi) } \\
& \text { Doç.Dr.Arzu Wasti(Sabancı University) }
\end{aligned}
$$

Dergide yaymlanan yazılardaki görüşler ve bu konudaki sorumluluk yazarlarna aittir.

Yaymlanan eserlerde yer alan tüm içerik kaynak gösterilmeden kullanılamaz.

All the opinions written in articles are under responsibilities of the outhors.

The published contents in the articles cannot be used without being cited 


\title{
İş Performansının Sağlanmasında Çalışanın Duygusal Emeğinin ve Örgütte Güven Algısının Etkileri
}

\author{
Dr. Memduh BEGENİRBAŞ \\ Dr. Ercan TURGUT \\ Kara Harp Okulu Dekanlığı
}

Kara Harp Okulu Dekanlığı, İşletme Bölüm Başkanlığ1

\section{ÖZET}

Bu araştırmada, örgütte güvenin, duygusal emek ve iş performansı üzerine etkileri araştırllmıştır. Ayrıca duygusal emeğin örgütte güven ve iş performansı arasında aracılık rolü olup olmadığına bakılmıştır. Bu maksatla, Ankara'da özel ve kamu bankalarında çalışan 162 katılımcıdan anket yoluyla elde edilen veriler analiz edilmiştir. Çalışmada değişkenler arası ilişkiler ve etkileri korelâsyon ve regresyon analizleri ile ortaya konurken, değişkenlere ait ölçeklerin doğrulanması esnasında yapısal eşitlik modelinden istifade edilmiştir. Elde edilen bulgular incelendiğinde, banka çalışanlarının örgütte güven algılarının duygusal emekleri ve iş performansları üzerinde önemli etkilere sahip olduğu görülmüştür. Özellikle, örgütte güven algllarl yüksek olan çalışanların yüzeysel rol yapmalarl düşük ve iş performanslarının ise yüksek olduğu tespit edilmiştir. Örgütte güvenin çalışanlardaki doğal duygu gösterimini de artırdı̆̆ görülmüştür. Ayrıca, çalışanların duygusal emeklerinin örgütte güven ve iş performansı arasında aracılık rolüne rastlanılmamıştır. Araştırmanın bulgularıyla ilintili olarak, iş performansının artırılmasına yönelik çalışanların temini ve idamesi için hizmet sektörü yöneticilerine de önerilerde bulunulmuştur.

Anahtar Kelimeler: Örgütte güven, duygusal emek, yüzeysel rol yapma, derinden rol yapma, iş performansı JEL Sinıflandırması: D23, M12

\section{ABSTRACT}

In this study, the effects of organizational trust to emotional labor and job performance are examined. And if available, the mediating role of emotional labor between organizational trust and job performance are also observed. For this purpose, data are obtained and analyzed from 162 private and public bank employees' working in Ankara. The relations and effects between variables are presented by correlation and regression analyses. The validity of scales are measured with structural equation model. According to the findings, it is seen that the perception of organizational trust of bank employees' has significant effects on their emotional labor and job performance. Particularly, it is found that when the perception of organizational trust of employees' are high, then their surface actings are low, but job performances are high. And also, it is observed that emotional labor does not have any mediating role between organizational trust and job performance. Furthermore depend on findings, some suggestions are made to the service sector managers aimed at providing productive and effective service emplooyees for increasing job performance.

Key Words: Organizational trust, emotional labor, surface acting, deep acting, job performance JEL Classification: D23, M12 


\section{Giriş}

Örgütler değişimin kaçınılmaz olduğu günümüz koşullarında yaşamlarını devam ettirirken, rakipleri ile başa çıkabilmeleri ve bu rekabeti sürdürebilmeleri onların istenilen ve gerekli olan performansı göstermelerine bağlıdır. $\mathrm{Bu}$ anlamda performansı etkileyebilecek her durum ve değişkenin örgütler açısından hayati öneme haiz olduğu düşünülmektedir. Günümüz şartlarında işletmelerin başarılı olabilmeleri, varlıklarını sürdürebilmeleri ve ortalamanın üzerinde gelir elde etmeleri rakiplerine göre daha yüksek performans göstermelerine bağlıdır (Becker ve Huselid, 1998). Performansın birçok tanımı olmasına rağmen genel olarak performans; işin bir parçası olarak çalışanların işe yönelik aktiviteleri şeklinde görülmektedir (Borman ve Motowidlo 1993). Örgütler, çalışanların davranışlarını anlamak, geleceğe yönelik tahminler yapmak ve çalışanların davranışlarını kontrol ederek onların verimliliğini ve dolayısıyla örgütsel etkinliği arttırmak gayreti içindedirler. Başarının anahtarı olan performans artışı, kendiliğinden gerçekleşen bir süreç olmadığı gibi birçok değişken ve faktörden de etkilenmektedir. Bu anlayışa paralel olarak, çalışanların davranışlarını anlamaya odaklı; duygusal emek ve örgütte güven gibi kavramların örgüt çalışanlarının verimliliği ve iş performansı açısından üzerinde önemle durulması gereken konular olduğu düşünülmektedir.

Bu kapsamda, örgütlerin müşteri memnuniyeti sağlama çabaları bir bakıma çalışanların bireysel performanslarıyla ilintili olduğu değerlendirilmektedir. Bu anlamda, hizmet alanların memnuniyetlerinin büyük oranda çalışanların sergidikleri duygu gösterimleriyle doğrudan ilişkisinin olduğu söylenebilir (Grandey, 2000). Bu durum, örgüt çalışanlarının hizmet alanlara karşı harcamış oldukları duygusal emeğin önemini artırmaktadır. Çalışanların görevleri esnasında gösterecekleri duygu gösterimleri onların işleri hakkındaki algı ve tutumlarını da ortaya koymaktadır (Hochschild, 1979). Hissetmediği halde, örgütün istediği duyguları sergilemek zorunda olan çalışanların belirli bir süre içerisinde iş performanslarının olumsuz yönde etkilenebileceği düşünülmektedir. $\mathrm{Bu}$ durumun tam tersi de mümkün olabilir. Yani, çalışanın içten gelen ve samimi olan duygulariyla görevini yerine getirmesi onun performansını artırabilecek ve dolayısıla örgütsel performansin da olumlu yönde etkilenmesi mümkün olabilecektir.

Çalışanların örgüte güven duymaları ve örgütte güven anlayışının hakim olması, organizasyonun etkinliği ve performansı açısından büyük rol oynamaktadır (Annamalai ve diğerleri, 2010). Güven oluşumunda, iki ya da daha fazla tarafın birlikte yarattıkları bir sosyal durum söz konusudur. Örgütte güven, örgüt içinde oluşan güven iklimi olup, örgütsel rollere, ilişkilere, deneyimlere day anarak örgüt üyelerinin, bireylerin niyetleri ve davranışları hakkındaki olumlu beklentileridir (Chathoth ve diğerleri, 2007). Örgütte güven ortamının tesis edilmesi bir bakıma örgütün sosyal hayatını felç olmaktan kurtaracak kadar etkili sonuçlar yaratabilmektedir (Mollering ve diğerleri, 2004). Örgütte güven ikliminin oluşumu ve sağlanması her anlamda çalışanlar tarafından memnuniyetle karşılanacağı düşüncesiyle, anılan güven ikliminin çalışanlarda duygusal olarak göreve yaklaşımlarında bazı değişiklikler oluşturabileceği düşünülmektedir.

$\mathrm{Bu}$ çalışmada, bankacılık sektöründe çalışanların örgütlerindeki güven algılarının ve görevlerini yerine getirirlerken göstermiş oldukları duygusal emek gösterimlerinin iş performanslarına etkilerini ortaya koymak temel amaç olarak belirlenmiştir. Ayrıca, bütüncül bir yaklaşım çerçevesinde, örgütteki güven algisının performansa etkisini ortaya koyarken, bu etkide duygusal emeğin aracilık rolünün olup olmadığının belirlenmesi de araştırmanın bir diğer amacını oluşturmaktadır. Özellikle hizmet sektöründeki mesleklerle ilgili yapılan araştırmalarda duygusal emek konusunun ele alınması sebebiyle (Steinberg ve Figart, 1999) araştırmanın katılımcılarının bankacılık sektörü çalışanlarından seçilmesinin çalışmanın yazına katkıları kapsamında anlamlı olabileceği değerlendirilmektedir. İlgili 
ulusal ve uluslararası yazın incelendiğinde, araştırmada ele alınan değişkenlerin tamamını bütüncül bir model olarak ele alan araştırmaya rastlanılmamış olması, ayrıca yazında sıklıkla rastlanılmayan duygusal emek konusunun bankacılık sektöründe çalışanlar üzerindeki etkilerine yönelik araştırmalara ulaşılamamış olması, bu çalışmanın önemli yanını oluşturmaktadır. Çalışanların iş performanslarını etkileyebileceği düşünülen söz konusu değişkenler ile oluşturulan bütüncül modelin analiz bulgularının yazına katkısı yanında, örgütlerin yönetim ve insan kaynakları departmanlarının planlamaları kapsaminda değerlendirilebileceği düşünülmektedir.

\section{Kavramsal Çerçeve}

\section{1. Örgütte Güven}

Son yıllarda örgütsel davranış alanında oldukça ilgi çeken ve araştırılan bir konu olarak karşımıza çıkan güven (Dirks ve Ferrin, 2002), bireyler arası ilişkilerin oluşturulmasinda ve devam ettirilmesinde önemli bir faktör ve disiplinler arası bakış açıları ile tanımlanan bir kavramdır (Uzbilek, 2006). Güven, örgütün uzun süre hayatta kalabilmesini sağlayan en önemli girdilerden biridir (Cook ve Wall, 1980). Örgüt yazını güven olgusunu, etkili ve performansı yüksek organizasyonlar için vazgeçilmez bir unsur olarak desteklemektedir (Hoy ve diğerleri, 1992; Darrough, 2006). Örgüt teorisyenleri de, yıllarca örgütteki güvenin önemini vurgulamışlardır (Kurşunoğlu, 2009). Yapılan araştırmalar neticesinde de güven kavramı konusunda uzlaşılan nokta, gerek birey, gerekse grup düzeyinde örgütler için sayısız yararının olduğudur (Dirks ve Ferin, 2001; Kramer, 1999). Örgütteki güveni, çalışanın örgütünün kendisine sağladığı her türlü desteğe ilişkin algıları, yöneticilerin ve çalışma arkadaşlarının dürüst olması ve kuşku duymadan onlara inanma olarak tanımladığımızda (Mishra ve Morrissey, 1990), güvenin hem yatay hem de dikey anlamda tüm örgüt içi ilişkilerin temelini oluşturduğunu söyleyebiliriz (Türköz ve diğerleri, 2013).
Ayrıca güven, farklı türdeki örgüt yapılarını ve örgütteki çalışanları bir arada tutan "sosyal yapıştırıcı" olarak ele alındığında (Puusa ve Tolvanen. 2006), örgütsel amaçların başarılmasında gerekli olan işbirliği ve ortak bağlılığın artırılmasında önemli rol oynamaktadır. Güven hem bireyler arası hem de kollektif bir olgu olduğundan, örgüt içinde güven birey, grup ve sistem düzeyinde olmak üzere üç şekilde incelenebilir (Puusa, Tolvanen. 2006). Bu kapsamda, örgütteki güven, birey düzeyinde karşılıklı olarak çalışanların birbirleriyle olan etkileşimlerine odaklanırken (Rotter, 1980), grup düzeyinde ise takımların paylaşılan değerler çerçevesinde ortak davranışlar sergilemeleri ve bu davranışların benimsenmesine dayalı kurallar geliştirmesi güven ortamını oluşturur. Grupların ortak davranış ve uygulamaları zamanla örgüt içinde kuramsallaşarak, güven bireysel düzeyde içselleştirilir ve sistem düzeyinde kurumsal hale gelir (Ülker, 2008).

Örgütsel ortamda gelişen kişiler arası güvenin, yazında yatay açıdan iş arkadaşlarına ve dikey olarak ise yöneticiye güven olmak üzere iki farklı açıdan ele alındığı görülmektedir (Yang, 2005; Costigan ve diğerleri, 1998). Çalışma arkadaşlarına güven kişinin meslektaşlarının yeterliliğini ve adil, itimat edilir ve etik ilkeleri benimseyen davranışları sergileyeceğine olan inancı olarak tanımlanabilir. Çalışma arkadaşlarına güven, çalışanları söylemlerinde ve eylemlerinde adil davranmaya yönlendirir. McAllister (1995) kişiler arası güveni, karşı tarafın sözlerinden, davranışlarından ve kararlarından emin olunması ve ilişki kurma yönünde harekete geçilmesi olarak nitelendirmektedir. Yöneticiler de örgüt içinde güven düzeyini belirlemede genel olarak merkezi rol oynamaktadır (Hubbell ve ChoryAssad, 2005). Bu anlamda, yöneticilerin inançları ve eylemleri doğrudan ve dolaylı olarak örgüt içinde güveni etkilemekte, yöneticinin güvenilir olması, verdiği söz ve vaatleri yerine getirecek kararlar vermeleri örgütteki güvenin tesisi açısından çok önemli hale gelmektedir (Deluga, 1994).

Chen'e göre (1998) ise, karşllıklı güven ilişkileri, çalışanların iş çevreleriyle olan 
temaslarında onlara yardım eden en önemli kavramlardan biridir. Bu ilişkiler tüm insanlar arası etkileşimler için geçerlidir. Ayrıca, güven ilişkilerinden yoksun şirket, organizasyon ve örgütlerde işbirliği ve yardımlaşmadan söz edilemeyeceği gibi, bu oluşumların geleceğinin olamayabileceği düşünülmektedir.

\subsection{Duygusal Emek}

Günümüz rekabete dayalı iş koşullarında, çalışanların işlerini yaparken sergiledikleri tutum ve davranışları ile alıcı konumundaki kişilere belirli bir duygusal mesajın gönderilmesi, artık birçok sektördeki, özellikle de hizmet sektöründeki mesleklerin görev tanımlarına dâhil edilmiş durumdadır. Bu kapsamda örgütler, çalışanlarının duygularını kullanmakta ve müşteri memnuniyetini en üst düzeyde tutmak istemektedirler. $\mathrm{Bu}$ düşüncenin oluşması duyguların aslında kişiye özel olmasına rağmen, günümüzde adeta ekonomik değeri olan, bir anlamda elle tutulur ve gözle görülebilir bir ürün haline gelmesine neden olmuştur (Özgen, 2010). Duygusal emek kavramını gerçek anlamda ve detaylı bir şekilde ilk defa ortaya çıkaran Hochschild (1983)'e göre duygusal emek; iş gereği duyguların diğerleri tarafindan gözlenecek şekilde düzenlenerek, yüzsel ve bedensel gösterimde bulunulmasıdır. Hochschild (1983), yüz yüze ve vücut hareketlerinin duygusal emeği yansıttığını belirtirken, ondan sonraki araştırmacılar bu açıklamalara ilave yapmışlar ve duygusal emeğin, iletişim esnasındaki ses tonu ve davranışlara yansıyan her türlü gayreti de içerdiğini söylemişlerdir (Rafaeli ve Sutton, 1987; Wharton, 1999). Asforth ve Humprey (1993) ise, duygusal emeği hislerin içsel yönetimden farklı olarak, gözlemlenebilir tutumlar şeklinde ele almışlardır. Hatta kişiler arası iletişim ve etkileşim esnasında örgütler tarafından gösterilmesi beklenilen ve arzu edilen duyguların, çalışanlar tarafından gösterilmesi için harcanması gereken gayret ve bu konuya yönelik olarak yapılan her türlü planlama ve kontrol gereksinimlerini de duygusal emek olarak tanımlamak mümkündür (Morris, Feldman, 1996). Ayrıca duygusal emek, karşımızdaki insanı anlamak için onun her davranış ve konuşmalarından alacağımız tüm ipuçları ve emarelere bakarak, kendi gerçek hissettiklerimizi baskılayarak gösterdiğimiz duygusal çalışma stratejisidir (Kleinman ve Copp, 1993).

Son yıllarda duyguların özellikle hizmet sektöründe kullanılması gerekliliği, duygusal emek kavramını ön plana çıkarmıştır (KiffinPetersen ve diğerleri, 2011). Hizmetin yerine getirilmesi esnasında çalışanların duygularının yönetilmesini ifade eden duygusal emeği Hochschild $(1979,1983)$ yüzeysel rol yapma ve derinden rol yapma olmak üzere iki boyutta ele almıştır. Yüzeysel rol yapma, çalışanların müşterilerine karşı gerçek hislerini değiştirmedikleri halde, duygu gösterimlerini kontrol ederek beklentilere uyumlu hale getirdikleri davranış biçimlerini ifade etmekte, yani duygularını gerçek hissettiği duygulardan farklılaştırarak, bir anlamda sahteleştirerek, karşısındaki müşteriye/alıcıya yansitmaktadır (Brotheridge ve Grandey, 2002; Hochschild, 1983). Diğer boyut ise, derinden rol yapmadir. Derinden rol yapmada his veya duygusal tepkiler kendiliğinden ortaya çıkmaktadır. Çalışan gerçek hislerini kendisinden beklenen davranışlarla uyumlu hale getirmeye çalışmakta (Grandey, 2003), başka bir ifadeyle çalışan, göstermek durumunda olduğu duyguyu bizzat tecrübe etmeye, yaşamaya ve içselleştirmeye çalışmaktadır (Diefendorff ve Gosserand, 2003). Ashforth ve Humphrey (1993), kişilerin rol gereklerini yerine getirmeleri için her zaman rol yapmaları gerekmediğini, bazı durumlarda gerçek hissettikleri duygularla, sergilemeleri gereken duygularm birbiriyle aynı olabileceğini ifade ederek, Hochschild'in iki boyutlu yaklaşımına üçüncü bir boyut olarak doğal (samimi) davranışları ilave etmiştir. Doğal davranışlar, çalışanların yansitmak durumunda oldukları duyguları içten gelerek hissediyor olmaları durumunda ortaya çıkan davranış türüdür ve gösterilmesi istenen davranış gerçekten hissedilmekte ve gösterilmektedir (Ashforth ve Humphrey, 1993).

Duygusal emek kavramını değişik alt boyutlar altında inceleyen araştırmalar (Morris ve 
Feldman, 1996; Kruml ve Geddes, 2000) olmasına karşın, yazın taraması neticesinde sıklıkla kullanılan yaklaşımın yüzeysel, derinden rol yapma ve doğal duyguları içeren yaklaşım olduğu (Diefendorff ve diğerleri, 2005) gerçeğinden hareketle, bu çalışmada da anılan üç boyutlu yaklaşım esas alınacaktır. Grandey (2000)'e göre duygusal emek, hizmet veren örgütler için gereklidir, çünkü bu örgütlerde çalışanlar, kurallar ve normlar gereği uygun duygusal emek gösteriminde bulunmak zorundadırlar. $\mathrm{Bu}$ kapsamda duygusal emek, yardım amaçlı, insanları koruyup kollayan ve hizmet tabanlı mesleklerde çalışanlarda (hemşireler, banka çalışanları, uçuş ve satış görevlileri, vb.) daha sıkça yaşanmaktadır (Pierce, 1995). Bu tespite göre araştırmamızın katılımcılarının bankacılık sektöründe faaliyet göstermesinin, araştırmanın yazına katkıları anlamında uygun olduğu değerlendirilmektedir.

\section{3 İş Performansı}

Performans örgütlerde belirli bir amacin, fonksiyonun veya görevin yürütülmesiyle ya da gerçekleştirilmesiyle ilişkili bir kavram olarak (Borman ve Motowidlo, 1993), bireyin işini yerine getirmek için harcamış olduğu tüm çabalar karşısında elde ettiği başarı düzeyidir (Büte, 2011). İş performansına yönelik yazın taramasında farklı tanımlara rastlamak mümkündür. Kohli (1985) performansı, çalışanın kendine eşdeğer çalışanlara kıyasla iş ile ilgili davranış ve çıktılarının verimlilik düzeyi olarak tanımlamış, Rousseau ve McLean (1993) ise, iş performansinı çalışanların ücret karşılığında sarf etmeleri gereken gayret olarak nitelendirmiştir. İş performansı, çalışan tarafından kontrol edilen ve organizasyonun hedeflerine ulaşmasına katkıda bulunan her türlü faaliyet ve davranış olarak da ele alınmaktadır (Rotundo ve Sackett, 2002). Hizmet sektöründe iş performansı, hem hizmet sunumu gibi somut, hem de kişiler arası davranış ve duygu gösterimleri gibi soyut görünümlü olarak karşımıza çıkabilir (Bitner ve diğerleri, 1990).

Günümüzde örgütlerin belirledikleri amaç ve hedeflerine ulaşabilmeleri, içinde bulundukları sektörlerde rekabet üstünlüklerini ellerinde bulundurarak ortalamanın üzerinde gelir elde etmeleri bir anlamda çalışanlarının yüksek performansları ile gerçekleşebilmektedir (Youndt ve Snell, 2004). Bu anlamda, örgütlerin yüksek performans gösteren çalışanlara ihtiyaçları vardır. Performans bir anlamda çalışanların ve örgütlerin etkililik göstergesidir (Richard ve diğerleri, 2008). Bu kapsamda iş performansı örgütler tarafından sürekli değerlendirmeye tabi tutularak geliştirilmesi ve yönlendirilmesine ihtiyaç duyulan bir örgütsel davranış değişkeni olarak ele alınmakta (Murphy ve Cleveland, 1995) ve insan kaynakları yönetiminde de önemli bir değişken olarak incelenmektedir (Motowidlo, 2003). Yöneticiler ile çalışanlar arasındaki etkileşimin karşılıklı güvene dayalı olacak şekilde tesisi çalışanların performansının artırılmasında yöneticilere düşen önemli görevlerden biridir (Çalışkan ve diğerleri, 2011). Çalışanların performanslarını belirleyen üç unsurdan söz edebiliriz (Paşa, 2007). Bunlar çalışanın işine kendini vermesini ifade eden odaklanma, bilgi ve beceriye dayalı yetkinlik ile örgüt amaçları ile çalışanın amaçlarının uyumunu ifade eden adanmadır. Yüksek bireysel performansin elde edilmesi bu üç unsuru birlikte ele alınmasını gerektirdiğinden, yönetim bu unsurların hangisinin, ne zaman ve ne kadarının gerektiğini belirlemek üzerine yoğunlaşmalıdır. Morillo (1990)'da performansı, bireyin sahip olduğu nitelikler ve yetenekler ile inanç ve değerlerine bağlamaktadır. Bireysel performans, örgütün amaçlarına ulaşabilmesi için çalışanın kullandığı yetkinliklere bağlı olarak, yalnızca işe yönelik görevleri değil, aynı zamanda işe yönelik olmayan görev ve davranışları da içermektedir (Mc Grath, 1995).

\section{4. Örgütte Güven, Duygusal Emek ve Performans İlişkisi}

Bireysel iş performansının örgütler açısından çok önemli bir çıktı olduğu düşünüldügünde, iş performansına her anlamda etki edebilecek değişken ve faktörlerin incelenmesinin örgütlerin devamı ve gelişimi anlamında kaçınılmaz olduğu gerçeğiyle karşılaşırız. Bu 
kapsamda örgütteki güvenin, örgüt ikliminin, işgören performansinın ve örgüte olan bağlılığın oluşmasında önemli bir faktör oluşturduğunu görmekteyiz (Laschinger ve diğerleri, 2001). Yapılan bir araştırmada da, yöneticilerinin kendilerine güven duydukları algısına sahip çalışanların daha çok sorumluluk aldıkları, buna bağlı olarak örgütlerinin satış ve hizmet performanslarının arttı̆̆ gözlemlenmiştir (Salamon ve Robinson, 2008). Yine konu hakkında yapılan bir meta analiz araştırmasına göre de (Gilboa ve diğerleri, 2008), örgütte güven ortamının tesis edilememesinin çalışanların performansını olumsuz yönde etkilediği ve örgütte güven ile iş performansı arasında pozitif bir ilişkinin olduğu yönündedir. Büte (2011)'de yaptığı bir araştırmada etik iklim, örgütsel güven ve performans arasında anlamlı ilişkiler tespit etmiştir. Karşllıklılık (Reciprocity) ilkesine göre de, çalışan-örgüt ilişkisinde karşılıklı beklenti ve memnuniyetin oluşturulması gereklidir (Levinson, 1965). Bu nedenle ister olumlu, isterse olumsuz karşılıklılık, sosyal sistemlerde ve özellikle örgütlerde dengenin sağlanmasında önemli bir rol oynamaktadır. $\mathrm{Bu}$ kapsamda değerlendirdiğimizde, çalışanların kendilerini güven ortamında hissetmeleri onların performanslarına olumlu katkılarda bulunabilecektir. Yukarıda bahsedilen kuram ve yazın araştırmaları ışığında, örgütteki güven ve iş performansına yönelik aşağıdaki hipotez geliştirilmiştir.

Hipotez 1: Örgütteki güven ortam1 çalışanların iş performansını pozitif ve anlamlı olarak etkiler.

Duygusal emek konusunda yapılan araştırmaların çoğu, duygusal emeğin birey ve örgüt üzerindeki etkilerini anlamaya yöneliktir. Genellikle vurgulanan, duygusal emeğin örgüt için faydalı, çalışan için zararlı sonuçlar ortaya çıarabileceğidir (Grandey, 2000). Duygusal emeğin bir alt boyutu olan yüzeysel rol yapmanın tükenmişlik (Grandey, 2000, Isenbarger ve Zembylas, 2006; Zhang ve Zhu, 2008), davranış samimiyetsizliği (Grandey, 2003; Brotheridge ve Lee, 2003) ile pozitif olarak ilişkilendirildiği görülmektedir. Tükenmişlik ile iş performansı arasında da negatif ilişkiler tespit edilmiştir (Randall ve Scott, 2011; Parker ve Kulik, 1995). Ancak, çalışanların duygu gösterimlerini içselleştirmeye çabaladıkları derin rol yapma ve samimi davranışlarını içeren doğal duygu gösterimlerinin ise kişisel başarma (Brotheridge ve Grandey, 2002), hizmet performansını artırması (Grandey, 2000), işten ayrılma niyetini azaltması (Chau, vd., 2009), işe bağlılı̆̆ı artırması (Öz, 2007) gibi pozitif sonuçlar yarattığı tespit edilmiştir. Duygusal Olaylar Teorisi (Weiss ve Cropanzano, 1996) örgüt içinde yaşanan olumlu ve olumsuz olayların çalışanların davranış değişikliklerine ve duygusal tepkilere neden olduğunu, bu kapsamda da çalışanlardaki pozitif duyguların olumlu davranışa, negatif duyguların ise olumsuz tutum ve davranışlara sebep olabileceğini vurgulamaktadır (Fisher ve Ashkanasy, 2000). Çalışanların örgüt içerisinde güven, memnuniyet, adalet, iş tatmini gibi pozitif duygular yaşaması, onların işlerine karş1 olumlu tutumlar beslemesine neden olurken (Grandey, 2000), aynı zamanda müşteriler ile iletişim ve etkileşimlerine de pozitif olarak yansımaktadır (Morris ve Feldman, 1996; Brotheridge ve Grandey, 2002). Anılan teori gereğince, çalışanların örgüt içerisinde güven ortamında olduklarına yönelik algılarının, onların olumlu duygu durumları içerisinde olmalarına etki edeceği ve bu çalışma atmosferinin de çalışanlarda daha yüksek performans değerleri yaratabileceği düşünülmektedir. Yukarıda bahsedilen kuram ve daha önce yapılan görgül araştırma bulguları neticesinde, örgütteki güven, duygusal emek ve iş performansına yönelik aşağıdaki hipotezler geliştirilmiştir.

Hipotez 2: Örgütteki güven ortamı çalışanların duygusal emeklerine etki eder.

Hipotez 2a: Örgütteki güven ortamı çalışanlarm yüzeysel rol yapmasin negatif ve anlaml olarak etkiler.

Hipotez 2b: Örgütteki güven ortamı çalı̧sanlarm derinden rol yapmasin pozitif ve anlaml olarak etkiler. 
Hipotez 2c: Örgütteki güven ortamı çalışanlarm doğal duygu gösterimlerini pozitif ve anlamlı olarak etkiler.

Hipotez 3: Çalışanların göstermiş oldukları duygusal emekleri iş performanslarını etkiler.

Hipotez 3a: Çalışanlarn yüzeysel rol yapmalan iş performanslarm negatif ve anlaml olarak etkiler.

Hipotez 3b: Çalışanlarm derinden rol yapması iş performanslarnı pozitif ve anlamlı olarak etkiler.

Hipotez 3c: Çalışanlarn doğal duygu gösterimleri is performanslarmı pozitif ve anlaml olarak etkiler.

Ayrıca araştırma kapsamında, yukarıdaki hipotezlerin test edilmesine yönelik analizler yapılırken, aynı zamanda ulusal ve uluslararası yazında karşılaşılmayan ancak olabileceği düşünülen örgütte güven ve iş performansı arasında duygusal emeğin muhtemel aracılık etkisine yönelik araştırma sorusuna da cevap aranmaya çalışılacaktır.

\section{Yöntem}

Araştırmada, korelasyonel araştırma deseni kullanılmıştır. Bu desen, ele alınan değişkenler arasındaki nedensel ilişkiyi, herhangi bir şekilde bu değişkenlere müdahale edilmeden ortaya koyma amacına yönelik olduğundan (Büyüköztürk ve diğerleri, 2008), çalışmada nedensel ilişkinin test edilebileceği bir katılımc1 grubundan istifade edilmiştir. Araştırma, anılan katılımcı grubundan, aşağıda ayrıntılı olarak açıklanan ölçeklerle toplanan verilerin analiziyle gerçekleştirilmiştir. Bu kapsamda, öncelikle her bir değişkenin doğrulayıcı faktör analizleri (DFA) yapısal eşitlik modeli kullanılarak yapılmış, daha sonra değişkenler arası korelâsyonlar ortaya konulmuş ve yapılan hiyerarşik regresyon analizi ile hipotezler ve aracılık etkileri test edilmiştir. Bu kapsamda, öncelikle iş performansı ve duygusal emeği yordayan demografik değişkenler ile örgütte güven değişkeninin hiyerarşik regresyon analizine yer verilmiş, daha sonra aracılık etkisi için söz konusu tüm değişkenleri içeren hiyerarşik regresyon analizi yapılmıştır. Kuramdan ve görgül araştırmalardan yola çıkılarak oluşturulan hipotezler ve yapılandırılan araştırma modeli Şekil 1' de gösterilmektedir.

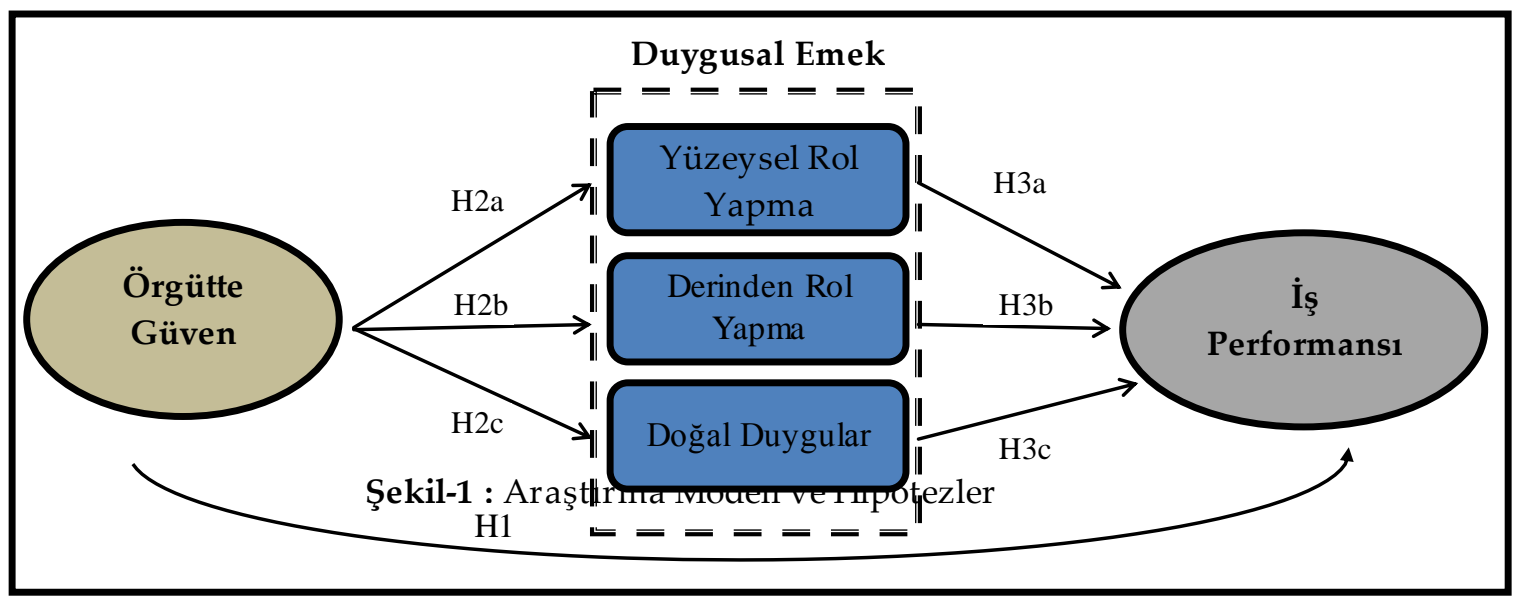

Şekil-1 : Araştırma Modeli ve Hipotezler 


\subsection{Katılımcilar}

Araştırmanın katılımcılarını, Ankara'da görev yapan veulaşılabilen banka sektörü çalışanları oluşturmaktadırlar. Araştırmada, ele alınan değişkenler arasındaki nedensel ilişkinin test edilebileceği ve araştırmanın kuramsal bağlamına uygun (convenience) bir kitle olması noktasindan hareketle, Ankara'da bulunan kamu ve özel sektör bünyesinde faaliyet gösteren değişik bankalarda çalışan toplam 278 personele anket formları ulaştırılarak, formların gönüllülük esasıyla doldurulması sağlanmıştır. Araştırmamızın amacı ele alınan değişkenler arası nedensel ilişkileri açıklamak olduğundan, söz konusu bankalarda görev yapan katılımcilar bu beklentiyi karşılamaktadırlar. Bu anketlerin 182' si geri toplanmıştır. Eksik ve ciddi doldurulmadığı belirlenen 9 anket ile uç analizi sonucunda 11 anket değerlendirme dişında birakılmış ve analizler 162 anket üzerinde yürütülmüştür.

Araştırma katılımcılarının \% 51'i (82) kadın, \% 49'u (80) erkektir. Medeni durumlarına bakıldığında, \% 63'ü (102)evli, \% 37'si (60) ise bekârdır. Ayrıca katılımciların \% 7'si (12) lise ve dengi okullar, , \% 77'si (124) lisans, \% 16's1 (26) ise yüksek lisans eğitimi düzeyine sahiptir. Katılımcıların \% 4'ü (6) 20-25 yaş, \% 11'i (19) 26-30 yaş arasında, \%51'i (82) 31-35 yaş arasında, \%28'i (45) ise 36-40 yaş ve \%6'sı (10) da 41 yaş ve üstüdür. Bunlardan \%25'i (41) kamu bankalarında görev yaparken, \%75'i (121) ise özel bankalarda çalışmaktadır.

\subsection{Araştırmada Kullanılan Ölçekler}

Örgütte Güven Ölçeği: Çalışanların örgütteki güven alg1sı Jarvenpaa ve arkadaşları (1998) tarafından kullanılan 6 maddeli ölçek ile ölçülmüştür. Ölçeğin Türkçe geçerlemesi Çelik ve arkadaşları (2011) tarafından yapılarak kullanılmıştır. Ölçekte cevaplar 5’li Likert ölçeği ile alınmıştır (1=Hiçbir Zaman, 5=Her Zaman). Ölçekteki maddeler "Genel anlamda, iş arkadaşlarım oldukça güvenilirdir", "Çalıştığım işyerinde bizler birbirimize güveniriz" şeklindeki maddelerden oluşmaktadır. Ölçeğin Jarvenpaa ve arkadaşları (1998) tarafindan yapılan güvenilirlik analizinde Cronbach alfa güvenirlik katsayısı .73, Çelik ve arkadaşları
(2011) tarafından yapılan araştırmada ise .71 olarak tespit edilmiştir. Yapısal eşitlik modeli kullanılarak ölçeğin DFA'sı yapılmıştır. DFA sonucunda ölçeğin uyum iyiliği değerleri kabul edilebilir sınırlar içerinde ve $\Delta \chi^{2}=9.393$, $\mathrm{sd}=8, \Delta \chi^{2} / \mathrm{sd}=1.174, \quad \mathrm{RMSEA}=0.041, \mathrm{CFI}=$ 0.99, GFI $=0.97, \quad$ AGFI $=0.92$ olarak tespit edilmiştir. Ölçeğin Cronbach alfa güvenirlik katsayısı ise $.77^{\prime}$ dir.

Duygusal Emek Ölçeği: Diefendorff ve arkadaşları (2005) tarafından iki farklı ölçekten istifade edilerek geliştirilmiş ve ölçeğin Türkçe geçerlemesi Basım ve Begenirbaş (2012) tarafından yapılarak kullanılmıştır. Ölçekte duygusal emek; yüzeysel rol yapma, derinden rol yapma ve doğal duygular olmak üzere üç alt boyutta toplam on üç maddeden oluşmaktadır. Ölçekte yüzeysel rol yapma 6, derinden rol yapma 4 ve doğal duygular ise 3 madde ile ölçülmektedir. Katılımcılar ölçek maddelerini beş basamaklı Likert Ölçeği yardımıyla değerlendirmişlerdir $(1=$ Hiçbir Zaman, 5= Her Zaman). Katılımclardan her bir madde için kendilerini en iyi ve gerçek olarak ifade eden seçenekleri işaretlemeleri istenmiştir. Ölçekteki maddeler, “Müşterilerle uygun şekilde ilgilenebilmek için rol yaparım", "Göstermem gereken duyguları gerçekte de hissetmek için çaba harcarım", "Müşterilere sergilediğim duygular samimidir" gibi maddelerden oluşmaktadır. Çalışmada ölçeğin geçerliliği için, Yapısal Eşitlik Modeli kullanılarak doğrulayıcı faktör analizi (DFA) yapılmıştır. DFA ile tek faktörlü, birinci düzey çok faktörlü, ikinci düzey çok faktörlü ve ilişkisiz model test edilmiştir. Test sonuçlarına göre birinci ve ikinci düzey çok faktörlü modelinde uyum iyiliği değerlerinin kabul edilebilir sınırlar içerisinde olduğu görülmüştür. Ancak birinci düzey çok faktörlü modelin uyum iyiliği değerleri daha iyi sonuç verdiğinden çalışmamızda birinci düzey çok faktörlü yapı benimsenmiştir. Birinci düzey çok faktörlü modele ait uyum iyiliği değerleri; $\Delta \chi^{2}=81.308$, $\mathrm{sd}=60, \Delta \chi^{2} / \mathrm{sd}=1.355, \quad \mathrm{RMSEA}=0.059, \mathrm{CFI}=$ 0.97, GFI $=0.90$, AGFI $=0.85^{\prime}$ tir. Duygusal emeğin her bir alt boyutu için Cronbach alfa katsayıları; yüzeysel rol yapma için .88, derinden rol yapma için .79, doğal duygular için ise .90 olarak bulunmuştur. Ölçeğin 
toplam iç tutarlığı ise .81 olarak tespit edilmiştir. Bu değerler ölçeğin geçerlilik ve güvenilirlik açısından yeterliliğe sahip olduğunu göstermektedir.

Işs Performansı Ölçeği: Çalışanların iş performansının ölçülmesinde; önce Kirkman ve Rosen (1999), daha sonra ise, Sigler ve Pearson (2000) tarafından kullanılan iş performansı ölçeği kullanılmıştır. Ölçek tek boyutlu ve 4 maddeden oluşmaktadır. Ölçeğin güvenirlik katsayısı her iki çalışmada da .70'in üstündedir. Türkiye'de Çöl (2008) tarafından akademisyenler üzerinde uygulanan ölçeğin güvenirlik katsayısı .82 olarak tespit edilmiştir. Araştırmada cevaplar 5'li Likert ölçeği ile alınmıştır (1=Hiçbir Zaman, 5=Her Zaman). Katılımcılardan her bir madde için kendilerini en iyi ve gerçek olarak ifade eden seçenekleri işaretlemeleri istenmiştir. Ölçekteki maddeler, "İşimde göstermiş olduğum performans düzeyim yüksektir", "Sunduğum hizmet kalitesinde standartlara fazlasiyla ulaştığımdan eminim" gibi maddelerden oluşmaktadır. Yapısal eşitlik modeli kullanılarak ölçeğin DFA'sı yapılmıştır. Yapılan DFA sonucunda ölçeğin tek faktörlü yapıya sahip olduğu, uyum iyiliği değerlerinin ise $\Delta \chi^{2}=3.015, \mathrm{sd}=2, \Delta \chi^{2} / \mathrm{sd}=1.507, \mathrm{RMSEA}=$ 0.070, $\mathrm{CFI}=0.99, \mathrm{GFI}=0.98, \mathrm{AGFI}=0.93$ olduğu tespit edilmiştir. Yapılan güvenirlik analizi sonucunda, iş performansına ait Cronbach Alfa katsayısı .85 olarak bulunmuştur.

\subsection{Bulgular}

Araştırmada öncelikle katılımcıların iş performansları, örgütte güven ve duygusal emek değişkeni alt boyutlarına ilişkin elde edilen verilerin ortalamaları, standart sapmaları ve aralarındaki korelasyonlara bakılmıştır. Analiz sonuçları Tablo-1'de görülmektedir.

Tablo-1 : Ortalama, Standart Sapma ve Korelasyon Değerleri

\begin{tabular}{lcccccccc}
\hline Değişkenler & & Ort. & $\begin{array}{c}\text { S. } \\
\text { Sap. }\end{array}$ & $\mathbf{1}$ & $\mathbf{2}$ & $\mathbf{3}$ & $\mathbf{4}$ & $\mathbf{5}$ \\
\hline İş Performansı & $\mathbf{( 1 )}$ & 3,83 &, 765 & $(, 85)$ & & & & \\
Örgütte Güven & $\mathbf{( 2 )}$ & 3,54 &, 577 &, $491^{* *}$ & $(, 77)$ & & & \\
Yüzeysel Rol Yapma & $\mathbf{( 3 )}$ & 2,48 &, 897 &,$- 232^{* *}$ &,$- 512^{* *}$ & $(, 88)$ & & \\
Derinden Rol Yapma & $\mathbf{( 4 )}$ & 3,17 &, 737 &, 106 &, 069 &,- 055 & $(, 79)$ & \\
Doğal Duygular & $\mathbf{( 5 )}$ & 3,92 &, 907 &, $200^{*}$ &, $344^{* *}$ &,$- 649^{* *}$ &, 118 & $(, 90)$ \\
\hline
\end{tabular}

** $\mathrm{p}<0,01$; $\mathrm{p}<0,05$ Not: Cronbach Alfa güvenilirlik katsayıları parantez içerisinde gösterilmiştir.

İş performansı ile örgütte güven arasında pozitif ve anlamlı ilişkiler tespit edilmiştir $(\mathrm{r}=0,491, \mathrm{p}<0,01)$. İş performansı ile yüzeysel rol yapma arasında negatif ve anlamlı ilişki tespit edilmişken $(\mathrm{r}=-0,232, \mathrm{p}<0,01)$, doğal duygular ile pozitif ilişki görülmektedir $(\mathrm{r}=0,200, \mathrm{p}<0,05)$. Ancak iş performansı ile derinden rol yapma arasinda anlamlı bir ilişkiye rastlanılmamıştır. Örgütte güven ile duygusal emek alt boyutları arasında, iş performansı ve duygusal emek alt boyutları arasındaki ilişkilere benzer ilişkiler görülmüştür.
Ayrıca, çalışmada ele alınan demografik değişkenlerin (eğitim, yaş, cinsiyet, medeni durum, çalıştığı kurum) diğer değişkenler üzerine etkilerini ortaya koymak maksadıyla iki ortalama arasında anlamlı fark olup olmadığını test etmek için $\mathrm{t}$ - testi, ikiden fazla ortalamaların karşılaştırılması için ise tek yönlü varyans analizi (ANOVA) yapılmıştır. Yapılan analiz sonuçları neticesinde sadece iş performansı ile katılımcıların çalıştıkları kurum arasında anlamlı bir fark tespit edilmiştir $\left[t_{(160)}=-3,857 ; p<0,01\right]$. Buna göre, özel bankalarda çalışan katılımcıların iş performans 
ortalamalarının kamu bankalarında çalışan katılımcılara göre anlamlı olarak daha yüksek olduğu söylenebilir.

Araştırmada, örgütte güven ve duygusal emeğin katılımcı banka çalışanlarının iş performanslarında bir etkiye sahip olup olmadığının ortaya çıkarılması ve oluşturulan hipotezlerin test edilmesi için hiyerarşik regresyon analizleri yapılmıştır. Regresyon analizlerinde demografik değişkenlerin etkilerinin kontrol altına alınması için birinci aşamada eğitim, yaş, cinsiyet, medeni durum ve çalışılan kurum değişkenleri modele girilmiştir. İkinci aşamada ise bağımsız değişkenler modele dâhil edilerek, bağımlı değişken üzerindeki etkileri belirlenmeye çalışılmıştır. İlk olarak, iş performansını etkileyen örgütte güvenin regresyon analizi yapılmış ve sonuçlar Tablo- 2'de sunulmuştur.

Tablo 2 : İş Performansını Yordayan Örgütte Güvenin Hiyerarşik Regresyon Analiz Sonuçları

\begin{tabular}{|c|c|c|}
\hline \multirow{2}{*}{ Bağımsız Değişkenler } & \multicolumn{2}{|c|}{ İş Performansı } \\
\hline & $\beta$ & $\Delta \mathbf{R}^{2}$ \\
\hline 1.Demografik Değişkenler & & 134 \\
\hline Eğitim & ,162 & \\
\hline Yaş & ,135 & \\
\hline Cinsiyet & ,034 & \\
\hline MedeniDurum &,- 020 & \\
\hline Kurum &, $338^{* *}$ & \\
\hline$\Delta \mathrm{F}$ & \multicolumn{2}{|c|}{$3,698^{* *}$} \\
\hline 2. Örgütte Güven & 450 & ,196 \\
\hline$\Delta \mathrm{F}$ & \multicolumn{2}{|c|}{$41,725^{* *}$} \\
\hline
\end{tabular}

${ }^{*} \mathrm{p}<0,05{ }^{* *} \mathrm{p}<0,01$

Tablo 2'den de görüldüğü üzere, iş performans1 genel olarak ele alınan demografik değişkenler $\left(\Delta \mathrm{F}=3,698, \Delta \mathrm{R}^{2}=0,134\right.$, $\mathrm{p}<0,01) \quad$ ve örgütte güven $(\Delta \mathrm{F}=41,725$, $\left.\Delta R^{2}=0,196, p<0,01\right)$ tarafindan anlamli olarak yordanmaktadır. Bu kapsamda, iş performansı demografik değişkenlerden sadece çalışılan kurum $(\beta=0,338, p<0,05)$ tarafindan anlamlı olarak açıklanmaktadır. Bu bulgular, örgütte güven hisseden çalışanların iş performanslarının daha yüksek olduğuna işaret etmekte ve Hipotez 1'i desteklemektedir. İkinci olarak, duygusal emek alt boyutlarını yordayan örgütte güvenin hiyerarşik regresyon analizine bakılmış olup sonuçlar Tablo-3'tedir. 
Tablo 3 : Duygusal Emeği Yordayan Örgütte Güvenin Hiyerarşik Regresyon Analiz Sonuçları

\begin{tabular}{|c|c|c|c|c|c|c|}
\hline \multirow[t]{2}{*}{ Bağımsız Değişkenler } & \multicolumn{2}{|c|}{$\begin{array}{c}\text { Yüzeysel } \\
\text { Rol Yapma }\end{array}$} & \multicolumn{2}{|c|}{$\begin{array}{l}\text { Derinden } \\
\text { Rol Yapma }\end{array}$} & \multicolumn{2}{|c|}{$\begin{array}{c}\text { Doğal } \\
\text { Duygular }\end{array}$} \\
\hline & $\bar{\beta}$ & $\Delta \mathbf{R}^{2}$ & $\bar{\beta}$ & $\Delta \mathbf{R}^{2}$ & $\bar{\beta}$ & $\Delta \mathbf{R}^{2}$ \\
\hline 1.Demografik Değişkenler & & ,012 & & ,046 & & 019 \\
\hline Eğitim & \multicolumn{2}{|l|}{,085 } & \multicolumn{2}{|l|}{,020 } & \multicolumn{2}{|l|}{,046 } \\
\hline Yaş & \multicolumn{2}{|l|}{071} & \multicolumn{2}{|l|}{-142} & \multicolumn{2}{|l|}{,- 171} \\
\hline Cinsiyet & \multicolumn{2}{|l|}{,- 009} & \multicolumn{2}{|l|}{,- 186} & \multicolumn{2}{|l|}{,- 025} \\
\hline MedeniDurum & \multicolumn{2}{|l|}{.005} & \multicolumn{2}{|l|}{,033 } & \multicolumn{2}{|l|}{,010 } \\
\hline Kurum &,- 033 & & ,006 & & \multicolumn{2}{|l|}{,088 } \\
\hline$\Delta \mathrm{F}$ & \multicolumn{2}{|c|}{,296 } & \multicolumn{2}{|c|}{1,159} & \multicolumn{2}{|c|}{,460 } \\
\hline 2. Örgütte Güven &,- 537 & 279 & 075 & ,005 & 352 & 120 \\
\hline$\Delta \mathrm{F}$ & \multicolumn{2}{|c|}{$56,341^{* *}$} & \multicolumn{2}{|c|}{,829 } & \multicolumn{2}{|c|}{$19,992^{* *}$} \\
\hline
\end{tabular}

${ }^{*} \mathrm{p}<0,05{ }^{* *} \mathrm{p}<0,01$

Bulgulara göre, genel olarak ele alınan tüm duygusal emek alt boyutlarının örgütte güveni anlamlı olarak yordamadığı tespit edilmiştir. Örgütte güven, duygusal emeğin yüzeysel rol yapma boyutunu negatif yordarken $(\beta=-0,537$, $\mathrm{p}<0,01)$, doğal duyguları ise pozitif ve anlamlı olarak yordamaktadır $(\beta=0,352, \mathrm{p}<0,01)$. Ancak örgütte güven derinden rol yapmayı anlamlı olarak etkilememektedir. Elde edilen bu sonuçlar, çalışmanın $2 a$ ve 2 c hipotezlerini desteklerken, Hipotez $2 \mathrm{~b}$ destek bulamamıştır.

Tablo 4 : İş Performansını Yordayan Duygusal Emek Boyutlarıve Örgütte Güvenin Hiyerarşik Regresyon Analiz Sonuçları

\begin{tabular}{|c|c|c|}
\hline \multirow{2}{*}{ Bağımsız Değişkenler } & \multicolumn{2}{|c|}{ İş Performansı } \\
\hline & $\beta$ & $\Delta \mathbf{R}^{2}$ \\
\hline 1. Demografik Değişkenler & & 134 \\
\hline Eğitim & ,162 & \\
\hline Yaş & 135 & \\
\hline Cinsiyet & ,034 & \\
\hline Medeni Durum &,- 020 & \\
\hline Kurum &, $338^{* *}$ & \\
\hline$\Delta \mathrm{F}$ & \multicolumn{2}{|c|}{$3,698^{* *}$} \\
\hline 2. Duygusal Emek & & 071 \\
\hline YüzeyselRol Yapma &,$- 241^{* *}$ & \\
\hline Derinden Rol Yapma & 130 & \\
\hline DoğalDuygular &, $195^{*}$ & \\
\hline$\Delta \mathrm{F}$ & \multicolumn{2}{|c|}{$4,199^{* *}$} \\
\hline 3. Örgütte Güven & 440 & 134 \\
\hline$\Delta \mathrm{F}$ & \multicolumn{2}{|c|}{$28,463^{* *}$} \\
\hline
\end{tabular}

${ }^{*} \mathrm{p}<0,05{ }^{* *} \mathrm{p}<0,01$ 
Çalışmada ortaya konan bir diğer hipotez, duygusal emeğin çalışanların iş performansı üzerinde etkisinin olduğudur. Bu hipotezi test emek için yapılan regresyon analizleri sonuçları Tablo 4'te belirtilmiştir. Buna göre, iş performansı genel olarak duygusal emek $\left(\Delta \mathrm{F}=4,199, \quad \Delta \mathrm{R}^{2}=0,071, \quad \mathrm{p}<0,01\right) \quad$ tarafindan anlamlı olarak yordanmaktadır. Başka bir deyişle, iş performansının toplam varyansının $\% \quad 7,1^{\prime} \mathrm{i}$ duygusal emek tarafindan açıklanmaktadır. Duygusal emeğin alt boyutları bazında baktığımızda da; yüzeysel rol yapma $(\beta=-0,241, p<0,01)$ ve doğal duygular $(\beta=0,195, \quad p<0,05)$ iş performansını anlamlı olarak yordarken, derinden rol yapma $(\beta=0,110, \quad p>0,05) \quad$ ise anlamlı olarak yordamamaktadır. Bulgular, yüzeysel rol yapma davranışı sergileyen çalışanların iş performanslarının düşük, doğal duygu gösteriminde bulunabilenlerin ise yüksek olabileceğini göstermektedir. Bu anlamda, duygusal emeğin iş performansı üzerinde anlamlı etkisi olduğu hipotezinde, Hipotez 3a ve $3 c$ desteklenirken, Hipotez $3 b$ ise destek görmemiştir.

Son olarak ise, örgütte güvenin iş performansina etkisinde duygusal emeğin aracılık etkisinin olup olmadığına bakılmıştır. Aracılık etkisinin olup olmadığının tespiti için Tablo 2, 3 ve 4'ün sonuçlarma birlikte bakılarak duygusal emeğin aracılık etkisi değerlendirilmiştir. Bu kapsamda, örgütte güvenin iş performansını anlamlı yordadığı (Tablo 2), duygusal emeğin iş performansını anlamlı etkilediği (Tablo 4) ve örgütte güvenin duygusal emeği genel anlamda anlamlı olarak açıkladığı (Tablo 3) görülmektedir. Tablo 4'e bakıldığında örgütte güvenin duygusal emek değişkenine rağmen iş performansına etkisinin $(\beta=0,440, \quad p<0,01)$ aracilık olmadan önceki etkisine $(\beta=0,450, \quad p<0,01)$ çok yakın ve etki farkının da Sobel testi neticesinde anlamsız çıtığı tespit edilmiştir $(\mathrm{z}=1,03, \mathrm{p}>0,05)$. Bu kapsamda araştırma sorusuna, duygusal emeğin örgütte güven ve iş performans1 arasında aracılık etkisine sahip olmadığı yanıtı verilebilir.

\section{Sonuç}

$\mathrm{Bu}$ araştırma, gerek normal gerekse iş hayatında insanlar arası ilişkilerde büyük önem arz eden ve son yıllarda da örgütsel davranış çalışmaları açısından değer kazanan ve önemli bir değişken olan örgütte güvenin önemini vurgulamaktadır. Ayrıca örgütte güvenin çalışanların duygusal emek gösterimleri ve iş performanslarına etkilerini de ortaya koymayı amaçlayan görgül bir araştırmadır. Çalışanların üstün iş performans göstermelerinin bir yolu da; örgütte güven ortamının mevcut olması (Türköz ve diğerleri, 2013) ve örgüte karşı olumsuz tutum ve davranışlar sergilemeyen, bu bağlamda iş esnasında içten gelen doğal duygularını yansıtan çalışanların istihdam edilmesine bağlıdır.

Araştırma neticesinde ulaşılan bulgular, katılımcı banka çalışanlarının görevlerini icra ederlerken örgüt içerinde güvenin olduğu algılarının onların iş performanslarına olumlu katkılar sağladığını göstermektedir. Bu bulgu daha önceki araştırmalarla da (Laschinger ve diğerleri, 2001; Salamon ve Robinson, 2008; Lee ve diğerleri, 2010; Büte, 2011) paralellik göstermekte ve banka çalışanlarının kendilerini çalıştıkları ortamda güvende hissetmediklerinde bu istenmeyen durumun onların iş performanslarına da olumsuz olarak yansıdığını, örgütte güven ortamının artmasının ise iş performanslarının yükselmesinde önemli bir etkiye sahip olabileceğine işaret etmektedir.

Araştırmada ayrıca, banka çalışanlarının duygusal emek gösterimlerinin onların iş performansları ile ilişkisine bakıldığında, iş performanslarının istemedikleri duyguları müşterilere göstermek zorunda kaldıklarında, yani yüzeysel rol yaptıklarında düştüğü, derinden rol yapma çabaları ile iş performansları arasında ise anlamlı bir ilişkiye rastlanılmadığı görülmektedir. Ancak, çalışma esnasında doğal duygularını sergileyebilen katılımcıların iş performanslarının da yükseldiği ve bu etkileşiminde anlamlı olduğu tespit edilmiştir. Bu bulgu konu hakkında yapılan daha önceki araştırmalarla da (Brotheridge ve Grandey, 2002; Grandey, 2003; Grandey ve diğerleri, 2005; Goodwin ve 
diğerleri, 2011) örtüşmekte ve özellikle hizmet çalışanlarının kendilerinin istemedikleri halde örgütlerinin istediği duygu gösterimlerini zorunlu olarak yaşamaları, onların iş performanslarını düşürmekte ve bu durumunda direk olarak örgütün genel performansına olumsuz olarak yansıyabileceği değerlendirilmektedir.

Çalışma ortamlarında görevlerini daha derinden hissederek, bir anlamda benimsemeye çaba göstererek yapan ve iyi niyetlibu gayretleri ile müşteri karşısına çıkan banka çalışanlarının ise, iş performanslarının olumlu yönde etkileneceği düşünülürken, araştırma bulguları bu iki değişken arasında anlamlı bir ilişki tespit edememiştir. Bu sonuç, Chau ve arkadaşları (2009), Cote ve Morgan (2002) ve Grandey (2000)'in çalışmalarında elde ettikleri bulguları desteklememektedir. Bu durum, banka çalışanlarının kurumlarının kendilerinden müşterilere karşı göstermelerini istedikleri duyguları içselleştirme çabaları esnasında zorlandıklarını ve bu gayretin iş performanslarına olumlu ve olumsuz herhangi bir etki yapmadığ şeklinde yorumlanabilir. Eğer derinden rol yapma zaman içinde içselleştirilebilir, doğal ve samimi duygulara dönüşebilirse çalışanların iş performanslarına olumlu katkılar sağlayabilecektir.

Araştırmanın bir diğer bulgusu da, örgütte güven algısının olmadığını düşünen çalışanların daha çok yüzeysel rol yapma eğilimi gösterdikleri, ancak örgütte güven algisının yükselmesiyle çalışanların müşterilerine daha doğal duygu gösterimleri sergilemeye eğilimli oldukları yönündedir. Elde edilen bulgular Morris ve Feldman (1996) ile Brotheridge ve Grandey 2002)'in yaptıkları araştırma bulguları ile benzerlik göstermektedir. Araştırmada ayrıca, çalışanların örgütte güven algılarının iş performanslarına etkisinde duygusal emek gösterimlerinin aracılık etkisine sahip olup olmadığ1 yönündeki araştırma sorusuna cevap aranmaya çalışılmış, ancak analizler neticesinde söz konusu aracıllk rolüne rastlanılmamıştır. $\mathrm{Bu}$ bulguya göre bir anlamda, çalışanların iş performanslarını gözetirken, araştırmada ele alınan örgütte güven ve duygusal emek değişkenlerinin iş performansina etkilerini ayrı ayrı değerlendirmenin daha doğru olacağını söyleyebiliriz.

Son zamanlarda örgütlerin güven kavramına ve özellikle çalışanların bu konu hakkındaki düşünce ve algılarına önem vermeleri, aynı zamanda soyut ve kişiye özel nitelikte olduğu bilinen çalışan duygularının günümüzde adeta ekonomik değeri olan somut bir ürün haline gelmiş olması (Özgen, 2010) araştırmanın önemini daha somut olarak ortaya koymaktadır. Özellikle son yıllarda, hizmet sektörünün de hızla büyümesiyle duygusal emek birçok hizmet alanı ve mesleğin vazgeçilmez ve yaygın bir bileşeni olarak dikkat çekmekte ve çalışanların iş performansları üzerindeki etkilerinin yadsınamaz olduğu görülmektedir. Bu nedenle, hizmet odaklı çalışan banka, güvenlik ve eğitim gibi sektörlerde çalışanların, örgütleri içinde algıladıkları güven ve duygu durumlarının göz önünde bulundurulması önem arz etmektedir. Dolayısıyla hizmet sektöründe faaliyet gösteren örgütlerin, örgütte güven ortamı tesis etmelerinin ve çalışanlarının gösterdikleri duygusal emeklerin negatif sonuçlarını azaltabilecek motivasyon araçları oluşturmalarının çalışanların performansını artırıcı yönde olabileceği değerlendirilmektedir.

Ayrıca, insan kaynakları yönetimi kapsamında, banka çalışanlarının seçim ve yerleştirme faaliyetleri, eğitim ve geliştirme süreçleri ile performans ve başarı değerlendirmesinde de, örgütte güven ortamının tesisinin ve çalışanların duygusal emek çabalarının birer etken olarak dikkate alınmasının, örgütün performans ve verimliliğine önemli katkılar sağlayacağı düşünülmektedir. Bu bağlamda, hizmet sektörü ve özellikle banka sektöründe faaliyet gösteren kurum ve kuruluşların bu çalışmanın bulgu ve sonuçlarını yönetim fonksiyonlarını uygularken değerlendirmeye alabilecekleri, özellikle insan kaynakları süreçlerinin daha etkin yürütülmesinde kullanabilecekleri ve çalışmanın bu anlamda sürece olumlu katkılar sağlayabileceği değerlendirilmektedir. 
$\mathrm{Bu}$ çalışma neticesinde ulaşılan bulgular ve sonuçlara göre, bundan sonra yapılacak araştırmalara zemin hazırlamak ve yön vermek maksadıyla araştırmacılara bazı önerilerde bulunulabilir. $\mathrm{Bu}$ kapsamda, çalışmada üç değişken olarak ele alınan ve oluşturulan model, araştırmacılar tarafından farklı öncül ve ardıl değişkenlerle ele alınarak zenginleştirilebilir. Örneğin, farklı demografik değişkenler ile duygusal emeği etkileyebilecek özellikle kişilik özelliklerine yönelik değişkenler kullanılarak araştırmalar yapılabilir. Ayrıca, duygusal emeğin etki edebileceği değerlendirilen diğer örgütsel davranış değişkenleri (örgütsel bağl1lık, örgütsel adalet, vb.) üzerine olan etkilerine de bakılarak yazına ve uygulayıcılara katkılar sağlanabilir. Ayrıca, örgütte güvenin kaçınılmaz olduğu, duygusal emeğin gerektiği

\section{Kaynakça}

Annamalai T., Abdullah A.G.K., Alazidiyeen N. J. (2010), "The Mediating Effects of Perceived Organizational Support on the Relationships Between Organizational Justice, Trust and Performance Appraisal in Malaysian Secondary Schools", European Journal of Social Sciences,13(4), 623-632.

Ashforth, B.E., Humphrey R.H. (1993), “Emotional Labor in Service Roles: The Influence of Identity", Academy of Management Review, 18.

Basım, H.N., Begenirbaş, M. “Çalışma Yaşamında Duygusal Emek: Bir Ölçek Uyarlama Çalışması", Celal Bayar Üniversitesi İktisadi ve İdari Bilimler Fakültesi Yönetim ve Ekonomi Dergisi, 19 (1), 2012, 77-90.

Becker, B.E., Huselid, M.A. (1998), High Performance Work Systems and Firm Performance: A Synthesis of Research and Managerial Implications. In Ferris, G.R. (ed.) Research in Personnel and Human Resources. Stamford, CT: JAI Press,

Bitner, M.J., Booms, B.H. Tetreault, M.S. (1990), "The Service Encounter: Diagnosing Favorable and Unfavorable Incidents", Journal of Marketing, 54, 71-84. ve iş performansının önemli olduğu değişik meslek dallarında (güvenlik, eğitim, sağlık, vb.) çalışan, nitel ve nicel olarak farklılaştırılmış katılımcı gruplarla yapılacak benzer çalışmalar, daha genellenebilir sonuçlara ve konu hakkında kapsayıcı meta analizlere dönüştürülebilir. Elde edilen bulguların yanında çalışma bazı sınırlılıklar da içermektedir. Araştırmanın katılımcılarının Ankara'da hizmet veren kamu ve özel banka çalışanlarından oluşması nedeniyle, bulgular doğal olarak, katılımcı özellikleriyle sınırlıdır. Bunların yanı sıra, veriler katılımcıların yalnızca kendi değerlendirmelerini yansıttığından, ortak yöntem varyansı ve sosyal beğenirlik sinırlılıkları, sonuçların değerlendirilmesinde dikkate alınmalıdır.

Borman, W. C., Motowidlo,S. J. (1993), “Expanding The Criterion Domain to Include Elements of Contextual Performance", (Ed.), Schmitt, N. ve Borman, W.C. PersonelSelection in Organizations, San Francisco, Ca: Jossey-Bass, 71-98.

Brotheridge, C., Grandey A. (2002), “Emotional Labor and Burnout: Comparing Two Perspectives of People Work", Journal of Vocational Behavior, 60, 17-39.

Brotheridge, C.M., Lee R.T. (2003), “Development and Validation of the Emotional Labor Scale", Journal of Occupational and Organizational Psychology, 76, 365-379.

Büte, M. (2011), “Etik İklim, Örgütsel Güven ve Bireysel Performans Arasındaki İlişki", Atatürk Üniversitesi Iktisadi ve İdari Bilimler Dergisi, 25(1), 171-192.

Büyüköztürk, Ş., Çakmak, E.K., Akgün, Ö.E., Karadeniz, Ş., Demirel, F. (2008), Bilimsel Araştırma Yöntemleri (gel. 2. bs.), Ankara: Pegem Akademi,

Chathoth, P.K., Mak, B., Jauhari, V., Manaktola, K. (2007), “ Employees' Perceptions of Organizational Trust and Service Climate: A Structural Model Combining Their Effects on Employee Satisfaction", Journal of Hospitality and Tourism Research, 31 (3), 338-357.

Chau, S.L. Dahling J.J., Levy P.E., Diefendorff J.M. (2009), “A Predictive Study of Emotional 
Labor and Turnover", Journal of Organizational Behavior, 30, 1151-1163.

Chen, H. F. (1998), "Significance and Function of Corporate Culture.", TaiZhong Normal College Academic Journal, 12, 1-22.

Cook, J., Wall, T. (1980), "New Work attitude Measures of Trust, Organizational Commitment and Personal Need Non Fulfillment", Journal of Occupational Psychology, 53, 39-52.

Costigan, R.D., Ilter, S.S., Berman, J. (1998). “A Multi-Dimensional Study of Trust in Organizations", Journal of Managerial Issues, 10,

Cote, S., Morgan, L.M. (2002), “A Longitudinal Analysis of The Association Between Emotion Regulation, Job Satisfaction, and Intentions To Quit", Journal of Organizational Behavior, 23, 947-962.

Çalışkan A., Akkoç, İ., Turunç, Ö. (2011), “Örgütsel Performansin Artırılmasinda Motivasyonel Davranısların Rolü: Yenilikçilik ve Girişimciliğin Aracilık Rolü", Süleyman Demirel Üniversitesi İktisadi ve İdari Bilimler Fakültesi Dergisi, 16(3), 363-401.

Çelik, M. Turunç, Ö., Begenirbaş, M. (2011), “ÖrgütselPerformansın Sağlanmasında Örgütte Güven, Tükenmişlik ve Kişiler Arası Çarpıklığın Rolü", Çă̆ Üniversitesi Sosyal Bilimle Dergisi, 8, 1, 1-29.

Çöl, G. (2008), “Algılanan Güçlendirmenin İş Gören Performansı Üzerine Etkileri", Doğuş Üniversitesi Dergisi, 9 (1) 35-46.

Darrough, O. G. (2006), An Examination of the Relationship Between Organizational Trust and Organizational Commitment in the Workforce, Doctoral Dissertation, Nova Southeastern University,

Deluga, R.J. (1994), “Supervisor Trust Building, Leader-Member Exchange and Organizational Citizenship Behaviors", Journal of Occupational and Organizational Psychology, 67, 315-326.

Diefendorff, J. M, Gosserand R. H. (2003), "Understanding the Emotional Labor process: A Control Theory Perspective", Journal of Organizational Behavior, 24, 945959.
Diefendorff, J.M., Croyle, M.H., Grosserand, R.H. (2005), “The Dimensionality and Antecedents of Emotinal Labor Stra te gies", Journal of Vocational Behavior, $66,339-357$.

Dirks, K.T., Ferrin, D.L. (2001), “ The Role of Trust in OrganizationalSettings", Organization Science, 12(4), 450-467.

Dirks, K.T., Ferrin D.L. (2002), “Trust in Leadership: Meta-Analytic Findings and Implications for Research and Practice", Journal of Applied Psychology, 87, 611-628.

Fisher, C.D., Ashkanasy, N.M. (2000), “Special Issue On Emotions In Work Life", Journal of Organizational Behavior, 21(3), 123-129.

Gilboa, S., Shirom, A., Fried, Y., Cooper C. (2008), "A Meta-analysis of Work Demand Stressors and Job Performance: Examining Main and Moderating Effects", Personnel Psychology, 61, 227271.

Goodwin, R.E., Markus G., Stephen J.F. (2011), "Relationships Between Emotional Labor, Job Performance and Turnover", Journal of Vocational Behavior, 79, 538-548.

Grandey, A. (2000), “Emotion Regulation in the Workplace: A New Way to Conce ptualize Emotional Labor", Journal of Occupational Health Psychology, 5, 95110.

Grandey, A. (2003), "When the Show must go on: Surface Acting and Deep Acting as Determinants of Emotional Exhaustion and Peer-rated Service Delivery", Academy of Management Journal, 46, 86-96.

Grandey, A.A., Fisk, G.M., Mattila, A.S., Jansen, K.J , Sideman, L.A. (2005), "Is Service with a Smile Enough? Authenticity of Positive Displays During Service Encounters", Organizational Behavior and Human Decision Processes, 96, 38-55.

Hochschild, A.R. The Managed Heart: Commercialization of Human Feeling, Berkeley, University of California Pres, 1983.

Hochschild, A.R. (1979), “Emotion Work, Feeling Rules, and Social Structure", American Journal of Sociology, 85(3), 551-75.

Hoy, W. K., Tarter, C.J., Witkoskie, L. (1992), "Faculty Trust in Colleagues: Linking 
The Principal With School Effectiveness", Journal of Research and Development in Education, 26 (1), 38-45.

Hubbell, A.P. , Chory-Assad. R.M. (2005), "Motivating Factors: Perceptions of Justice and Their Relationship with Managerial and Organizational Trust". Communication Studies, 56(1), 47- 70.

Isenbarger, L., Zembylas, S.M. (2006), “The Emotional Labor of Caring in Teaching", Teaching and Teacher Education, 22, 120134.

Jarvenpaa, S. L., Knoll, K., Leidner, D. E. (1998), “Is anybody out there?: The Implications of Trust in Global Virtual Teams" Journal of Management Information Systems, 14(4), 2964 .

Kiffin-Petersen, S.A., Catherine L.J., Geoffrey N.S. (2011), "The Big Five, Emotional Exhaustion and Citizenship Behaviors in Service Settings: The mediating Role of Emotional Labor", Personality and Individual Differences, 50, 43-48.

Kirkman, B.L., Rosen, B. (1999), “Beyond SelfManagement: Antecedents and Consequences of Team Empowerment", Academy of Management Journal, 42(1), 5874 .

Kleinman, S., Copp M.A. Emotions and Fieldwork, Sage Publications, Newbury Park, CA, 1993.

Kohli, A.K. (1985), “Some Unexplored Supervisory Behaviors and Their Influence on Salespeople's Role Clarity, Specific SelfEsteem, Job Satisfaction, and Motivation", Journal of Marketing Research, $22,424-433$

Kramer, R.M. (1999), “Trust and Distrust in Organizations: Emerging Perspectives, Enduring Questions", Annual Review of Psychology, 50, 569- 598.

Kruml, S.M., Geddes, D. (2000), “Exploring The Dimensions of Emotional Labor: The Hearth of Hochschild's Work", Management Communication Quarterly, 14, 8-49.

Kurşunoğlu. A. (2009), “An Investigation of Organizational Trust Level of Teachers According to Some Variables" Procedia Social and Behavioral Sciences, 1, 915-920.

Laschinger H.K.S., Finegan J., Shamian J., Wilk P. (2001), "Impact of Structural and
Psychological Empowerment on Job Strain in Nursing Work Settings: Expanding Kanter's Model", Journal of Nursing Administration, 31, 260-272.

Lee, P., Gillespie, N., Mann, L., Wearing, A. (2010), "Leadership and Trust: Their Effect on Knowledge Sharing and Team Performance", Management Learning,41(4), 473-49.

Levinson, H. (1965), “Reciprocation: The Relationship Between Man and Organization", Administrative Science Quarterly, 9, 370-390.

Mcallister, D.J. (1995), “Affect and Cognition Based Trust as Foundations for Interpersonal Cooperation in Organizations", Academy of Management Journal, 38(1), 24-59.

Mc Grath, R.G. (1995), “Defining and Developing Competence", Strategic Management Journal, 16(4), 251-275.

Mishra, J. , Morrissey, M.A. (1990), “Trust in Employee-Employer Relationships: A Survey of West Michigan Managers", Personnel Management, 19, 443-485.

Mollering, G., Backmann, R. ve Lee, S. H. (2004), “Understanding Organizational TrustFoundations, Constellations and Issues of Operationalisation (eds). The Micro Foundations of Organizational", Trust, Journal of Managerial Psychology, 19, 6.

Morillo, C.R. (1990), "The Reward Event and Motivation," The Journal of Philosophy, 87(4), 270.

Morris, J.A., Feldman D.C. (1996), “The Dimensions, Antecedents, and Consequences of Emotional Labor", Academy of Management Review, 21, 986-1010.

Motowidlo, S.J. (2003), Job Performance, Handbook of Psychology, 39-53.

Murphy, K.R., Cleveland, J. (1995), Understanding Performance Appraisal: Social, Organizational, and Goal-Based Perspectives, London:Sage Pub.

Öz, E.Ü. (2007), Duygusal Emek Davranışlarının Çalışanların İş Sonuçlarına Etkisi, İstanbul: Beta Yayınları.

Özgen, I. (2010), Turizm İşletmelerinde Duygusal Emek, Detay Yayıncılık, Ankara.

Parker, P., Kulik, J.A. (1995), “Burnout, Self- and Supervisor-Rated Job Performance, and 
Absenteeism Among Nurse s", Journal of Behavioral Medicine, 18(6), 581-599.

Paşa, M. (2007), Stresin Bireysel Performans Üzerindeki Etkileri ve Bir Uygulama, Uludağ Üniversitesi Sosyal Bilimler Enstitüsü, Doktora Tezi.

Pierce, J.L. (1995), Gender Trials:Emotional Lives in Contemporary Law Firms, University of California Press, Berkeley.

Puusa, A. , Tolvanen, (2006), U. “Organizational Identity and Trust", Electronic Journal of Business Ethics and Organization Studies, 11, 29-33.

Rafaeli, A., Sutton R. (1987), “Expression of Emotion As Part of The Work Role", Academy of Management Review, 12(1), 2337,

Randall, M, Scott, W.A. (2011), “Burnout, Job Satisfaction, and Job Performance", Australian Psychologist, 23(3), 335-347.

Richard, P.J., Devinney, T.M., Yip, G.S., Johnson, G. (2008), “ Measuring Organizational Performance as a Dependent Variable: Towards Methodological Best Practice", Journal of Management, 35(3), 718-804.

Rotter, J.B. (1980), “Interpersonal Trust, TrustWorthiness and Gullibility", American Psychologist, 35, 1-7.

Rotundo, M., Sackett, P.R. (2002), "The Relative Importance of Task, Citizenship, and Counterproductive Performance to Global Ratings of Job Performance: A Policy Capturing Approach", Journal of Applied Psychology, 87, 66-80.

Rousseau, D. M., McLean P. J. (1993), “The Contracts of Individuals and Organizations", Research in Organizational Behavior, 15, 1-43.

Salamon, S.D., Robinson, S.L. "Trust That Binds: The Impact of Collective Felt Trust on Organizational Performance", Journal of Applied Psychology, 93(3), 2008, 593-601.

Sigler, T.H., Pearson, C.M. (2000), “Creating An Empowering Culture: Examining The Relationship Between Organizational Culture and Perceptions of Empowerment", Journal of Quality Management, 5, 27-52.
Steinberg, R.J., Figart.D.M. (1999), “Emotional Demands at Work: A Job Content Analysis", The ANNALS of the American Academy of Political and Social Science, 561(1), 177-191.

Türköz, T., Polat, M., Coşar, S. (2013), “Çalışanların Örgütsel Güven ve Sinizm Algılarının Örgütsel Bağlılıkları Üzerindeki Rolü", Celal Bayar Üniversitesi I.İ.B.F Yönetim ve Ekonomi, 20(2), 285-302.

Uzbilek, A. (2006), Örgütlerde Oluşan Sosyal İlişkilerin Örgütsel Güvenin Alt Boyutlarına Etkileri: Başkent Üniversitesi Örneği, Yüksek Lisans Tezi, Ankara, Başkent Üniversitesi Sosyal Bilimler Enstitüsü.

Ülker, G. (2008), “Çalışanların Örgütsel Adalet Algılamalarının Yönetici ve Örgüte Duyulan Güven Üzerindeki Etkisi", Sosyal Bilimler Enstitüsü Dergisi, 16(1), 188-208.

Weiss, H.M., Cropanzano R. (1996), “Affective Events The ory: A Theoretical Discussion Of The Structure, Causes And Consequences Of Affective Experiences At Work", Research in Organizational Behavior, 18(1), 1-79.

Wharton, A.S. (1999), “The Psychological Consequences of Emotional Labour", The Annals of the American Academy of Political and Social Science, 561, 158-176.

Yang, J. (2005), The Role of Trust in Organizations: Do Foci ve Bases Matter?, Doctoral Dissertation, University of Louisiana State.

Youndt, M.A., Snell S.A. (2004), “Human Resource Configurations, Intellectual Capital, and Organizational Performance" Journal of Managerial Issues, 16(3), 337-360.

Zhang, Q., Zhu, W. (2008), “Exploring Emotion in Teaching: Emotional Labor, Burnout and Satisfaction in Chinese Higher Education", Communication Education, 57 (1), 105-122. 